Gut, 1981, 22, 332-335

Case reports

\title{
Hepatocellular carcinoma in HBsAg-negative chronic active hepatitis
}

\author{
P J JENKINS, * W M MELIA, B PORTMANN, \\ JENNIFER M LONGWORTH KRAFFT, $\dagger$ AND ROGER WILLIAMS
}

From the Liver Unit and Department of Morbid Anatomy, King's College Hospital and Medical School, London

SUMMARY The occurrence of hepatocellular carcinoma in HBsAg-negative chronic active hepatitis is described in two patients. Signs of the tumour appeared 18 years and nine years after the first clinical signs of chronic active hepatitis, although in one patient analysis of stored sera showed the serum alpha-fetoprotein levels had been rising over the previous 33 months. Female preponderance in HBsAg-negative chronic active hepatitis may partly account for the rarity of this complication, and the occurrence of hepatocellular carcinoma may also be a reflection of the better survival now being obtained in HBsAg-negative chronic active hepatitis.

Hepatocellular carcinoma is a well-recognised complication of long-standing cirrhosis and a particularly high frequency has been reported in cirrhosis consequent on $\mathrm{HBsAg}$-positive CAH. ${ }^{1}$ In patients with the HBsAg-negative form of the disease, it has been stated to occur rarely, if ever, ${ }^{2}$ although examination of five large series ${ }^{3-7}$ reveals, of the 322 cases included, three apparent instances, all male, in which hepatocellular carcinoma developed. The development of hepatocellular carcinoma in a 60 year old Italian man in whom serum autoantibodies were negative has also been reported from Australia. ${ }^{8}$ In none of these patients, however, had an earlier hepatitis B virus infection been completely excluded by examination of serum for all virus markers, particularly antibody to hepatitis $B$ core antigen, and few details of the patients are given.

In this report, we describe two patients with HBsAg-negative CAH in whom hepatocellular carcinoma developed 18 years and nine years after the first clinical signs of their disease. In one of them, aged only 22 years at death, subsequent analysis of stored sera showed rise in serum alpha-fetoprotein (AFP) levels, which was first detected 33 months before signs of the tumour became evident.

*Present address: Alfred Hospital, Melbourne 3181, Australia. +Present address: Department of Pathology, Kingston General Hospital, Kingston-upon-Thames, Surrey.

Received for publication 30 September 1980.

\section{Case 1}

A 27 year old English woman was admitted to Guy's Hospital in October 1953 with a six month history of anorexia, recurrent jaundice, and polyarthralgia. Investigations showed a raised erythrocyte sedimentation rate of $110 / \mathrm{mm} / \mathrm{h}$, in addition to abnormalities of liver functions (serum bilirubin $62 \mu \mathrm{mol} / 1$, alkaline phosphatase 167/IU/l, albumin $21 \mathrm{~g} / 1$, and total globulin $67 \mathrm{~g} / \mathrm{l})$. Jaundice and joint symptoms quickly resolved with prednisolone, $15 \mathrm{mg}$ daily, which was reduced after a few weeks to $10 \mathrm{mg}$ daily on which she continued until 1966, when she was readmitted with another episode of jaundice. Examination showed palmar erythema, numerous spider naevi, and hepatomegaly $(3 \mathrm{~cm}$ below right costal margin). The characteristic features of $\mathrm{CAH}$ which had progressed to cirrhosis were found on liver biopsy, with evidence of continuing activity including piecemeal necrosis and infiltration of the portal tract with mononuclear cells. She responded quickly to a temporary increase in prednisolone dosage (30 mg daily) and for the next four years was maintained on prednisolone (10-15 mg daily).

In January 1971 she was readmitted to hospital with symptoms of increasing jaundice and rightsided abdominal pain. On examination, the liver was notably tender (palpable $4 \mathrm{~cm}$ below the right costal margin) but results of liver function tests showed little change with a serum bilirubin level of $98 \mu \mathrm{mol} / 1$, 


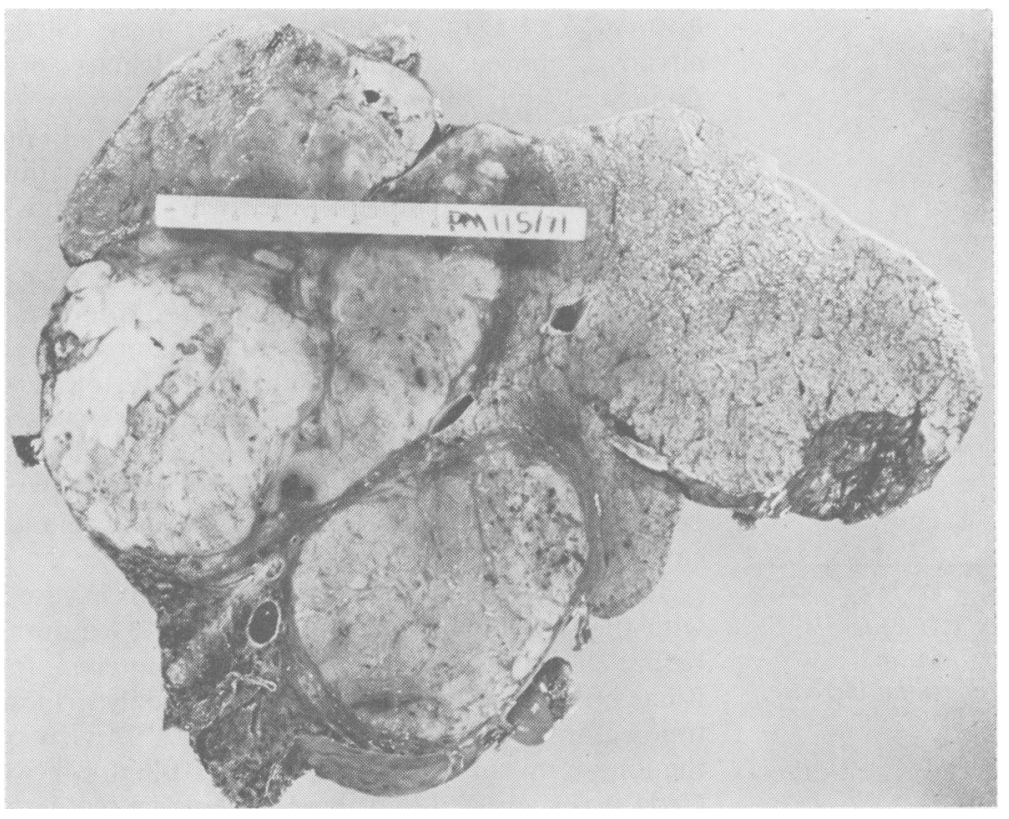

Fig. 1 Case 1. Transection of liver, showing tumour replacing the right lobe and a macronodular cirrhosis in uninvolved areas (original scale 1:1.75).

alkaline phosphatase of $180 \mathrm{IU} / 1$, aspartate aminotransferase $130 \mathrm{IU} / 1$, albumin $33 \mathrm{~g} / \mathrm{l}$, and globulin $37 \mathrm{~g} / \mathrm{l}$. Antibodies to smooth muscle $(++)$ and antinuclear factor $(++)$ were present in serum. Over the next six weeks abdominal pain and distension became increasingly severe and she was transferred to King's College Hospital, but died 48 hours after admission. Serum taken on this admission was negative for AFP, HBsAg, and anti-HBs when tested at a later stage by radioimmunoassay (HBsAg: Ausria II, Anti-HBs:Ausab, Abbott Laboratories, Basingstoke, Hampshire, England).

Necropsy showed an enlarged liver, weighing $4190 \mathrm{~g}$, with a macronodular $(0 \cdot 5-1 \mathrm{~cm})$ cirrhosis. The whole of the right lobe was replaced by tumour tissue (Fig. 1) and on histological examination the appearances were those of a well-differentiated hepatocellular carcinoma.

\section{Case 2}

A 13 year old boy was admitted to King's College Hospital in 1970 with a 12 week history of malaise and jaundice, and a previous episode of jaundice lasting two weeks in 1964. Details of his family history, in which there was a high frequency of autoimmune disease and serum autoantibodies, are described elsewhere. ${ }^{9}$ Examination revealed spider naevi and hepatomegaly. Liver function tests showed serum bilirubin $68 \mu \mathrm{mol} / 1$, aspartate aminotransferase $1220 \mathrm{IU} / 1$, alkaline phosphatase $366 \mathrm{IU} / 1$, pro- thrombin time 18 seconds (control 13 seconds), albumin $33 \mathrm{~g} / 1$, total globulin $77 \mathrm{~g} / \mathrm{l}, \operatorname{IgG} 45 \cdot 60 \mathrm{~g} / \mathrm{l}$. Antinuclear factor was positive in the serum (titre $1: 80$ ) as were smooth muscle antibodies (titre 1:80). Liver biopsy showed changes characteristic of chronic active hepatitis at the cirrhotic stage. Lymphocytic portal tract infiltration and piecemeal necrosis were marked. He was started on prednisolone and azathioprine, and over the next four years was reasonably well, although serum AST remained raised (60-160 IU/1).

In August 1975 he became jaundiced again and the serum AST rose to $1035 \mathrm{IU} / 1$ and total globulin to $53 \mathrm{~g} / \mathrm{l}$. With an increased dose of prednisolone $(40 \mathrm{mg}$ daily) some clinical and biochemical improvement occurred.

Finally in June 1979, he was readmitted with a six week history of increasing abdominal pain, fever, and jaundice. Serum bilirubin had risen to $730 \mu \mathrm{mol} / 1$ and AST to $1090 \mathrm{IU} / 1$. On palpation, the liver was tender and larger than previously. The clinical diagnosis of hepatocellular carcinoma was supported by the finding of a greatly raised AFP (see below); but neither $\mathrm{HBsAg}$, anti-HBs or anti-HBc were detected in radioimmunoassay (anti-HBc:Corab, Abbott Laboratories, Basingstoke, Hampshire, England).

Necropsy revealed an enlarged liver (weighing $21900 \mathrm{~g}$ ) with a coarse macronodular cirrhosis. On sectioning, the left lobe was found to be completely replaced by necrotic tumour and tumour nodules were also present in the right lobe, the histological 


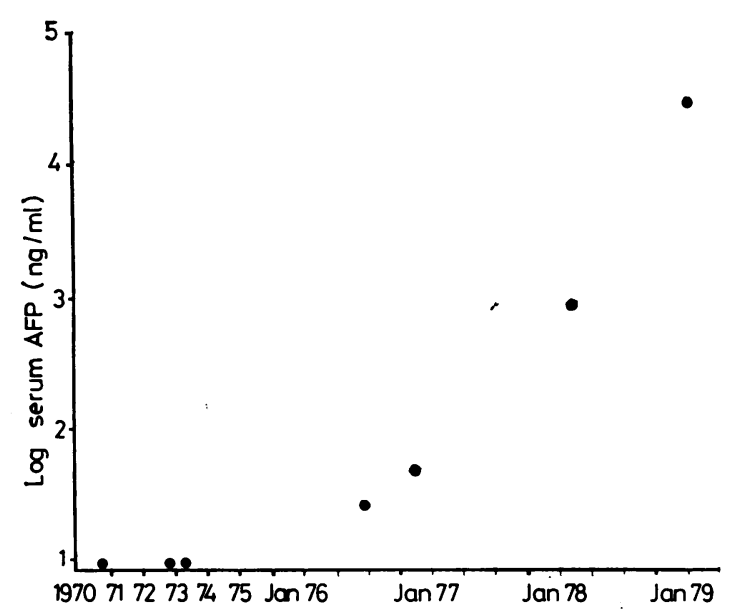

Fig. 2 Case 2. Serial alpha-fetoprotein (AFP) levels over a nine-year period, showing the first rise in September 1976 and the subsequent exponential increase.

appearance being that of a moderately well-differentiated hepatocellular carcinoma.

\section{SERIAL AFP ESTIMATIONS}

Sera were available from the Unit serum bank from 1970 onwards. Using a sensitive radiommunoassay which yields a range of $2-10 \mathrm{ng} / \mathrm{ml}$ in healthy subjects, ${ }^{10}$ a raised serum AFP was detected for the first time in September 1976, 33 months before tumour became clinically manifest (Fig. 2). From then onwards there was an exponential rise in serum concentration to a level of $100000 \mathrm{ng} / \mathrm{ml}$ at time of final admission.

\section{Discussion}

There can be no doubt about the diagnosis of HBsAg-negative CAH in these two patients. The initial presentation in each case was with relapsing jaundice, and laboratory findings of hyperglobulinaemia and anti-smooth muscle antibodies in the serum, as well as the histological appearances, were all characteristic of this condition. Serological investigations were negative for hepatitis $B$ virus infection (including absence of anti-HBc in case 2).

As already referred to, there have, to date, been no well-documented cases of hepatocellular carcinoma in HBsAg-negative CAH in women. The marked female sex predominance in this disease is likely to be one of the reasons why the complication of hepatocellular carcinoma is encountered so rarely. Tumour development is found particularly in those types of cirrhosis which occur predominantly in the male-for instance, alcoholic cirrhosis and HBsAg-positive CAH. Hepatocellular carcinoma is also very rare in patients with primary biliary cirrhosis, another condition in which females predominate, and, of the four cases reported by us recently, one was male. ${ }^{11}$ The duration of the cirrhosis is also important and, until the introduction of prednisolone treatment, the overall prognosis for chronic active hepatitis was poor. However, with such therapy life expectancy is considerably prolonged, and in the recently published follow-up study from the Royal Free Hospital ${ }^{12}$ patients lived 10 years or longer. Our two patients had histological evidence of cirrhosis five and nine years before clinical signs of the tumour appeared. Studies in alcoholics have susgested that cirrhosis must have been present for five to 10 years for a hepatocellular carcinoma to develop. ${ }^{13}$

The results of the serum AFP estimations in case 2 with the findings of a raised level some 33 months before clinical evidence of tumour is of interest, for it has been reported that the level rises only a short time before the onset of the symptoms..$^{14}$ In view of the long-term survival now seen in HBsAg-negative CAH it is suggested that these patients be regularly monitored for changes in serum AFP levels, as cytotoxic drug therapy, particularly Adriamycin, can now give a worthwhile remission in at least $20 \%$ of patients with hepatocellular carcinoma. ${ }^{15}$

We are indebted to the Pathology Department for their help and to the Cancer Research Campaign for support.

\section{References}

1Johnson PJ, Krasner N, Portmann B, Eddleston ALWF, Williams R. Hepatocellular carcinoma in Great Britain. Influence of age, sex, HBsAg status, and aetiology of underlying cirrhosis. Gut 1978; 19: 1022-6.

'Edmonson HA, Peters RL. The liver. In: Anderson WAD, Kissane JM, eds. Pathology volume 2. St. Louis: Mosby, 1977: 1321-438.

${ }^{3}$ Read AE, Sherlock S, Harrison CV. Active juvenile cirrhosis considered as part of a systemic disease and the effect of corticosteroid therapy. Gut 1963; 4: 378-93. ${ }^{4}$ Mistilis SP, Skyring AP, Blackburn GRB. Natural history of active chronic hepatitis. I: Clinical features, course, diagnostic criteria, morbidity, mortality and survival. Australas Ann Med 1968; 17: 214-23.

${ }^{5}$ Cook CG, Mulligan R, Sherlock S. Controlled prospective trial of corticosteroid therapy in active chronic hepatitis. $Q J$ Med 1971; 40: 159-85.

'Soloway RD, Summerskill WHJ, Baggenstoss AH, Geall MG, Gitnick GL, Elveback LR, Schoenfield LJ. Clinical biochemical and histological remission of severe chronic active liver disease: a controlled study of treatments and early prognosis. Gastroenterology 1972; 63: 820-33.

${ }^{7}$ Murray-Lyon IM, Stern RB, Williams R. Controlled 
trial of prednisone and azathioprine in active chronic hepatitis. Lancet 1973; 1: 735-7.

${ }^{8}$ Joske RA, Laurence BH, Matz LR. Familial active chronic hepatitis with hepatocellular carcinoma. Report of a case. Gastroenterology 1972; 62: 441-4.

'Galbraith RM, Smith M, Mackenzie RM, Tee DE, Doniach $\mathbf{D}$, Williams $\mathbf{R}$. High prevalence of seroimmunologic abnormalities in relatives of patients with active chronic hepatitis or primary biliary cirrhosis. N Engl J Med 1974; 290: 63-9.

${ }^{10}$ Johnson PJ, Portmann B, Williams R. Alpha-fetoprotein concentrations measured by radioimmunoassay in diagnosing and excluding hepatocellular carcinoma. Br Med J 1978; 2: 661-3.

${ }^{1}$ Krasner N, Johnson PJ, Portmann B, Watkinson G, MacSween RNM, Williams R. Hepatocellular carcinoma in primary biliary cirrhosis: report of four cases. Gut 1979; 20: 255-8.

${ }^{12}$ Kirk AP, Jain S, Pocock S, Thomas HC, Sherlock S. Late results of the Royal Free Hospital prospective controlled trial of prednisolone therapy in hepatitis B surface antigen negative chronic active hepatitis. Gut 1980; 21 : 78-83.

13Purtilo DT, Gottlieb LS. Cirrhosis and hepatoma occurring at Boston City Hospital (1917-68). Lancet $1973 ; 32$ : 458-62.

${ }^{14}$ Kubo Y, Okuda K, Musha H, Nakashima T. Detection of hepatocellular carcinoma during a clinical follow-up of chronic liver disease: observation in 31 patients. Gastroenterology 1978; 74: 578-82.

${ }^{15}$ Williams R, Melia WM. Liver tumours and their management. Clin Radiol 1980; 31: 1-11. 